\title{
IN VITRO CALLUS INDUCTION AND SHOOT REGENERATION POTENTIALS IN SOME SNAKE MELON ACCESSIONS COLLECTED FROM DIFFERENT REGIONS IN EGYPT
}

\author{
Mohamed $^{1}$ F.H., Abo-Zeid ${ }^{2}$ A.A.I., Abd El-Hamed ${ }^{1 *}$ K.E., Elwan ${ }^{1}$ M.W. \\ and Abdel Salam ${ }^{2}$ M.M.
}

1- Horticulture Dept., Fac. of Agric., Suez Canal Univ., Ismailia, Egypt.

2- Horticulture Research Institute, Agric. Research Centre, Dokki, Giza, Egypt.

${ }^{*}$ Corresponding author: khalidegy1@yahoo.com

Received 13 May, 2019

Accepted 13 October, 2019

\section{ABSTRACT}

Several snake melon genotypes are grown in different locations in Egypt. However, the relationships and the degree of relatness among these genotypes are not well documented. This study was carried out with the aim to classify different Egyptian snake melon genotypes based on the in vitro callus induction and shoot regeneration potential. Nine snake melon accessions (acc.) were collected from different regions in Egypt, including acc.3 (Damietta), acc.7 (Bany Swief), acc.8 (Fayoum), acc.9 (Giza), acc.11 (Menia), acc.14 (Sohag), acc. 15 (Behaira-Wady Elnatron), acc. 17 (Ismailia) and acc. 18 (Behaira-Badr Center). Twenty seeds from each accession were sterilized and cultured in vitro on MS medium basal salt and vitamins for 4 weeks. Segments $(4 \times 4 \mathrm{~mm}$ each) from cotyledon were used as explants and cultured on MS medium amended with $2.0 \mathrm{mg} / \mathrm{L}$ TDZ for callus induction. The formed callus was sub cultured onto MS medium amended with $3.0 \mathrm{mg} / \mathrm{L}$ $\mathrm{BA}+4 \mathrm{ml}$ Hyaluronic acid for shoot regeneration. Results indicated that the degree of callus formation was different among the different accessions. Based on callus growth potential measured as fresh weight, snake melon accessions could be ranked as: acc. $9>$ acc. $18>$ acc. $3=$ acc. $11>$ acc. $17>$ acc. $15>$ acc. $8=$ acc. $14>$ acc. 7 . Significant differences among the accessions were also observed for their shoot regeneration potential from callus. The highest number of shoots per explant was recorded in acc. 18 (ave.12.6 shoots), followed by acc.9, 11 , and 7 which produced an average of $10.8,10.4$, and 9.8 shoots, respectively. Results suggested that snake melon genotypes with high callus induction had also high regeneration capaci-
\end{abstract}

ty. In addition, these accessions could have different genetic background, which might help in future breeding programs to improve plant and agronomic traits. The current in vitro callus induction and shoot regeneration technique in snake melon will also aid in future effort for germplasm preservation of accessions with unique characteristics.

Keywords: Cucumis melo var. flexuosus, accessions, callus induction, shoot regeneration, Hyaluronic acid, TDZ.

\section{INTRODUCTION}

Genotypic variation regarding the induction of morphogenetically competence cultures has been widely documented for several plant species. Such variations in the in vitro morphogenetic capacity were attributed to several factors such as explant source, physiological state of donor plant or culture conditions. However, several reports suggested that the induction of callus or organogenesis was under genetic control, and chromosomal location of the factors responsible for in vitro expression of morphogenesis has been identified early in wheat and rye (Higgins and Mathias, 1987; Lazar et al 1987).

In Chevrier et al 1990 found highly significant genetic differences for callus induction and regeneration of shoots in wheat, suggested that additive variance was an important factor in the inheritance of in vitro regeneration. In other study, Ampormah-Dwamena et al (1997) screened 22 lettuce genotypes for their response to regeneration in tissue culture and reported that shoot regeneration was strongly dependent on genotype. They showed no correlation between callus index 
and shoot regeneration index. In addition, variation in the in vitro performance of the examined genotypes was not statistically linked to their morphological groups. The approaches utilized in their experiment enable the ranking and discrimination among genotypes based on the in vitro organogenic capacity.

In Cucurbits, highly significant differences in shoot forming capacity was reported among different genotypes of muskmelon (Sebastiani and Ficcadenti 2016; Zhang et al 2011 and Ficcadenti \& Rotino, 1995), Cucurbita spp. (Gisbert et al 2011), and Cucumber (Mohamed et al 2005).

The difficulty in introducing novel variability in melon by inter specific and inter generic hybridization pose great limitation to improvement by traditional breeding methods (Nunez-Palenius et al 2008). Biotic methods such as genetic engineering, molecular biology and tissue culture techniques are capable of surpassing the natural genetic barriers, leading to the improvement of plant material and allowing the characterization of important horticultural traits.

Extensive screening of genotypes and modifying tissue culture conditions have greatly improved in vitro shoot regeneration of melon. In most research efforts, the focus was on testing factors affecting in vitro morphogenesis. However, limited studies have been directed to examine genotype differences. In melon, results of Molina \& Nnez (1995) indicated that it was possible to detect genotypic variations when the genotypes differ by at least $10 \%$ in their regeneration frequency. Several other reports also pointed out the existence of genetic variability affecting regeneration ability between melon cultivars (Blackmon \& Reynolds, 1982; Bouabdallah \& Branchard, 1986; Orts et al 1987; Mackay et al 1988, Dirks \& Buggenum, 1989; Niedz et al 1989; Oridate et al 1992). Monlia and Nuesz (1995) suggested that the existence of genetic variability in the in vitro melon regeneration could offer possibility of using this type of variation in future improvement programs. Heredity models for in vitro regeneration were developed by several authors for melon in order to classify genotype based on their regeneration capacity or callus induction. In this respect, Nadolska-Orezyk and Malepszy (1989) classified genotypes on the basis of percent explants that developed embryogenic callus, and found a wide range of variation for the investigated trait within one genotype.
Orts et al (1987) classified 15 melon cultivars and accessions collected from different countries on the basis of percent calli with shoot buds and percent of calli with developed shoots in vitro. They found significant differences among the 15 genotypes and concluded that genetic variation in the in vitro shoot regeneration frequency would allow studies of the genetic control of this character. It was shown that six genotypes recorded more than $50 \%$ calli with shoot buds, while the percent calli with developed shoots was $44 \%$ in best, and $0.0 \%$ in the least genotypes. Similar findings were recorded by Molina and Nuez (1995) who examined variations in shoot regeneration capacity among seed population of Cucumis melo L. cv. Cantaloupe, and the study of Ficcacdenti and Rotino (1995) on eleven Cucumis melo var. reticulatus and inodorus.

Optimization of in vitro shoot regeneration in the family Cucurbitaceae was previously studied in muskmelon; winter squash (Lee et al 2003); watermelon (Compton and Gray, 1993); summer squash (Ananthakrishnan et al 1993); bottle gourd (Han et al 2005), and cucumber (Curuk et al 2003). However, little studies have been conducted on the in vitro callus induction and plant regeneration in snake melon. The only available reports on this respect were those of Yalcin-Mendi et al (2010a) on a local Turkish genotype (46 $\mathrm{KSU}$ ), and Yalcin-Mendi et al (2010b) on snake melon accession (Acur NEfe 34). The same Turkish research groups (Comlekcioglu et al 2009) have also reported on factors affecting somatic embryogenesis/embryonic callus induction from snake melon cotyledonary explants of un-known genotype. In the above mentioned articles, the focus was only directed to examine the best hormonal type and concentration, explant source and environmental conditions during culture incubation, and only one snake melon genotype, in each report, was used.

In their first trail, Yalcin-Mendi et al (2010a) examined several hormonal combinations (BA+IAA) and culture conditions for best shoot regeneration from cotyledonary segment explant. They found that the highest adventitious shoot regeneration rate (42.8) was obtained on MS medium supplemented with $1.0 \mathrm{mg} / \mathrm{L} B A+0.25 \mathrm{mg} / \mathrm{L}$ IAA using explants from dark-grown seedlings. No data were recorded on number of shoots regenerated per explants or the degree of callus formation. In their second study (Yalcin-Mendi et al 2010b) they obtained better shoot regeneration rate $(88 \%)$ 

melon accessions collected from different regions in Egypt

from cotyledonary explants on MS medium supplemented with $0.5 \mathrm{mg} / \mathrm{L} \mathrm{BA}+0.5 \mathrm{mg} / \mathrm{L}$ IAA. Callus was formed on most explants on medium with $B A$. Comlekcioglu et al (2009) developed a protocol for in vitro regeneration by somatic embryogenesis in snake melon and reported the formation of callus on MS medium with high concentration of 2,4-D or NAA.

In the previous in vitro studies on snake melon, low BA concentrations were examined (0.25-2.0 $\mathrm{mg} / \mathrm{L}$ ) in combinations with IAA for shoot regeneration, or 2.4-D for callus induction. These plant growth regulators were not effective in our preliminary trail with the Egyptian snake melon accessions. However, results of Keng and Hoong (2005) on muskmelon showed high shoot regeneration capacity with high concentration of BA (8.0 $\mathrm{mg} / \mathrm{L}$ ) in the medium. Therefore, higher BA concentrations than those examined before and the use of TDZ (Thidiazuron) may need to be examined. TDZ was very effective in the regeneration of shoots from leaf disc in strawberry (Mohamed et al 2007). It was also shown by Gray (1993) that TDZ stimulated the induction of somatic embryos in melon compared to BA, Kin, or 2ip. In addition, Hyaluronic acid (HA) was reported as new substance with high potential for in vitro shoot regeneration (Kaewjampa et al 2012) and need to be tried in snake melon tissue culture.

In the present study, variability among Egyptian snake melon accessions collected from different regions were examined based on their in vitro callus induction and regeneration capacity as a new approach to classify and seek possible relationship among the tested genotypes.

\section{MATERIAL AND METHODS}

Variations among snake melon genotypes collected from different regions in Egypt were studied in vitro for both callus formation and shoot regeneration capacity based on the hypothesis that the genetic makeup of a plant genotype determines its in vitro performance in terms of callus induction and regeneration.

The plant materials included nine snake melon accessions, three from North Delta (acc. No.15, 3 and 18 which belong to Wady El-Natron, Behaira, Damietta, and Badr center, Behaira, respectively); one accession from middle delta (acc. No. 17 belong to Ismailia; five accessions from South Delta (8, 9,11,7 and14) belong to Fayoum, Giza, Menia, Bany Swif and Sohag, respectively.

\section{In vitro procedures}

\section{Callus induction experiment}

Seeds from the different accessions were first sterilized by rinsing with tap water for $5 \mathrm{~min}$, dipped in 70 Ethanol for $10 \mathrm{sec}$. followed by $5 \mathrm{~min}$ in $20 \%$ commercial bleach solution (Clorox) containing 1\% $\mathrm{NaOCl}$, then rinsed 3times in sterile distilled water. In a Laminar air-flow hood, seeds were cultured to germinate on a medium containing MS (Murashige and Skoog, 1962) basal salts and vitamins supplemented with $30 \mathrm{~g}$ sucrose. Medium $\mathrm{pH}$ was adjusted to 5.7 before adding $7.0 \mathrm{~g} / \mathrm{L}$ agar, then autoclaved for $30 \mathrm{~min}$ at $121^{\circ} \mathrm{C}$ and 15 psi. Seeds were grown on the surface of the agar-solidified medium in a glass jars (ca. $300 \mathrm{ml}$ ) as 5 seeds/jar. Cultures were incubated in a growth room at $24 \pm 2 \mathrm{C}^{\circ}$ with $16 \mathrm{hr}$ photoperiod under light of $60 \mu \mathrm{md} \mathrm{m}^{-2} \mathrm{~S}^{-1}$. After 21 days from incubation, seeds were germinated into healthy seedling with fully developed cotyledons. The degree of callus formation among the different accessions was tested using cotyledonary explant segment (5X5 $\mathrm{mm}$ ) from the middle of each cotyledon. Explants were cultured (abaxial surface up) on MS medium basal salts and vitamins amended with $30 \mathrm{~g} / \mathrm{L}$ sucrose and $2.0 \mathrm{mg} / \mathrm{L} \mathrm{TDZ}$ or BA. Media were solidified with $7.0 \mathrm{~g} / \mathrm{L}$ agar after adjusting $\mathrm{pH}$ to 5.7 . Each accession was replicated 5 times (5 jars) containing $30 \mathrm{ml}$ medium/jar, using three explants per jar. Cultures were incubated under dark condition for 2 weeks followed by light condition (16hr photoperiod, illumination of $45 \mu \mathrm{mol} \mathrm{min}^{-2} \mathrm{~S}^{-1}$ ) for another 3 weeks. Cultures were arranged on the growth room shelves in a complete randomized design. Data were collected on callus proliferation potential by measuring callus fresh weight $(\mathrm{g})$ and growth scale ( $1=$ small, $2=$ medium, and $3=$ massive callus). All cultured explants from the tested snake melon accessions have formed callus on MS medium supplemented with2.0 mg/L TDZ, but no callus was formed on MS+BA.

\section{Shoot regeneration experiment}

Calli formed from each accession were transferred to MS medium supplemented with $8.0 \mathrm{mg} / \mathrm{L}$ $\mathrm{BA}$ and $4 \mathrm{ml}$ of $\mathrm{HA}$ acid to examine the difference among snake melon genotypes in their shoot regeneration capacity. Three calli were cultured per glass jar, each containing $30 \mathrm{ml}$ medium. Five jars (replicates) were utilized per each accession and incubated on the shelves of the growth room in a 
CRD design. After 6 weeks in culture, shoot regeneration potential was examined by measuring $\%$ of callus with developed shoots, number of shoots regenerated, regenerated cluster fresh weight $(\mathrm{g})$, and number of fully developed buds.

\section{Statistical Analysis}

Data were subjected to the analysis of variance with means values compared with Duncan's multiple range test at $5 \%$ according to Steel and Torrie (1980)

\section{RESULTS AND DISCUSSION}

In the present study, callus and shoot /bud regeneration potential of nine snake melon accessions collected from different regions in Egypt were examined in a trial to rank these accessions and seek possible relationship based on the in vitro performance in two experiments.

In the first experiment, callus formation was achieved from the culture of cotyledonary explant on MS medium supplement $2.0 \mathrm{mg} / \mathrm{L}$ TDZ. Explants from all tested accessions had formed callus, mostly yellowish to white in color ranging from friable to compact callus. However, results revealed that the degree of callus formation was different among the different snake melon accessions as shown in Table (1) and Fig. (2). In this regards, callus fresh weight (FW) was significantly higher in accession No.9 (4.6 g) and No. 18 (4.16 g). Accession No.3 and No.11 were similar in callus FW (3.88g), followed by acc. No.7, 17 and 15 (Table 1). The least average callus $F W$ was recorded in acc. No. 14. Similarly, callus rating tested in a scale from 1-3 indicated that acc. No.18, 17, 9, 11 and 7 were not significantly different and were the highest in callus mass than the rest of snake melon accessions in vitro.

Ranking scale is a qualitative trait, while measure of FW is a quantitative trait, therefore, ranking the performance based on the later measure could be more reliable than the former one. In this regards, the 9 snake melon accessions could be ranked as fellow: acc. No. $9>=18>3=11>7=$ $17>15>8=14$. It is worth to mention that none of the cultured explants had formed callus on MS medium amended with $2.0 \mathrm{mg} / \mathrm{L} \mathrm{BA}$ (Fig. 1) as compared to those on MS+ TDZ and this effect was true in all tested accessions except No.9 which showed little callus on medium supplemented with BA.
The above mentioned results indicated that all accessions examined had the potential to produce callus in vitro, irrespective of the source from which they were collected. However, the degree of callus formation showed significant differences among accessions. The acc. No.9 (from Giza) and No.18 (from Behaira, Badr) were almost similar in callus performance and showed best callus growth, while acc. No.8 (Fayoum) and No.14 (Sohag) recorded the least callus growth. It may be possible that the later accessions are genetically different than the former, especially being grown in greater distance from each other.

The good effectiveness of TDZ on the induction of callus from cotyledonary explant of snake melon in this study is the first to be reported, and went in agreement with other articles using different plant species, i.e. Gondval et al (2016) on medicinal herb and Trivedi et al (2010) on asparagus. It was reported by Murthy et al (1998) that TDZ has several effects in vitro since it exhibits the unique properties of both cytokinins and auxins.

In the second experiment for shoot regeneration, the subculture of callus onto medium supplemented with $8 \mathrm{mg} / \mathrm{L} \mathrm{BA}+0.4 \% \mathrm{HA}$ resulted in the formation of shoot buds after 4 weeks (Figs. 3 and 4). It was found that all accessions had regenerated shoots on this medium, but in different degree, depending on the genotype (Table 1). In this respect, the highest significant shoot cluster FW was recorded in acc.No.7 (5.53g), followed by acc. No.18 (5.17g) and acc. No.9 (4.98g). The least shoot cluster FW was found in acc. No.17 (3.64g). With respect to the number of regenerated shoots per explant, results revealed that acc. No.18 significantly produced the highest shoot number (12.6) followed by accessionsNo.9, 11 and 7 which produced10.8, 10.4, and 9.8 shoots/cluster, respectively. Adventitious shoot regeneration was significantly the least from callus of acc. No.15 (only 4.8 shoot/explants). Some accessions regenerated fully developed leaves from the shoot cluster with an average between 1.2 to1.4 leaf in acc. No.3, 9, and 7, as shown in Table (1).

Based on the recorded number of regenerated shoots, the potential for shoot regeneration in the tested accessions could be ranked as follow: Acc. No.18 (Behaira, Badr) >Acc. No.9 (Giza = Acc. No.11 (Menia) = Acc. No.7 (BanySwif) > Acc. No.17 (Ismailia) = Acc. No.3 (Damietta) > Acc. No.14 (Sohag) > Acc. No.8 (Fayoum) > Acc. No.15 (Behaira, Wady El-Natron). These results suggest that some snake melon genotypes (No.18, 9, 11, and 7 ) had greater potential to regenerate shoots 

melon accessions collected from different regions in Egypt

Table 1. In vitro callus induction and regeneration capacity of nine Egyptian snake melon accessions

\begin{tabular}{|c|c|c|c|c|c|}
\hline \multirow{2}{*}{$\begin{array}{l}\text { Acc. * } \\
\text { (No.) }\end{array}$} & \multicolumn{2}{|c|}{ Callus mass ${ }^{\star \star}$} & \multicolumn{2}{|c|}{ Shoot regeneration ${ }^{\star * \star}$} & \multirow{2}{*}{$\begin{array}{c}\text { Fully } \\
\text { Developed leaf } \\
\text { (No.) }\end{array}$} \\
\hline & $\begin{array}{l}\text { FW } \\
(g)\end{array}$ & $\begin{array}{l}\text { Rating } \\
\text { Scale }\end{array}$ & $\begin{array}{l}\text { FW } \\
\text { (g) }\end{array}$ & $\begin{array}{l}\text { Shoot/cluster } \\
\text { (No.) }\end{array}$ & \\
\hline 15 & $3.22 \mathrm{c}$ & $2 b$ & $4.36 \mathrm{~b}$ & $4.8 \mathrm{e}$ & $0.2 \mathrm{~b}$ \\
\hline 3 & $3.86 \mathrm{~b}$ & $2 b$ & $4.08 \mathrm{bc}$ & $8.8 \mathrm{bc}$ & $1.4 \mathrm{a}$ \\
\hline 18 & $4.16 \mathrm{ab}$ & $3 a$ & $5.17 \mathrm{ab}$ & $12.6 \mathrm{a}$ & $1.2 \mathrm{ab}$ \\
\hline 17 & $3.51 \mathrm{bc}$ & $3 a$ & $3.64 \mathrm{c}$ & $9.0 \mathrm{bc}$ & $0.2 \mathrm{~b}$ \\
\hline 8 & $2.85 d$ & $2 b$ & $4.24 \mathrm{~b}$ & $7.2 \mathrm{~d}$ & $0.2 b$ \\
\hline 9 & $4.26 \mathrm{a}$ & $3 a$ & $4.98 \mathrm{ab}$ & $10.8 \mathrm{~b}$ & $1.4 \mathrm{a}$ \\
\hline 11 & $3.88 \mathrm{~b}$ & $3 a$ & $4.55 \mathrm{~b}$ & $10.4 \mathrm{~b}$ & $0.2 \mathrm{~b}$ \\
\hline 7 & $3.52 \mathrm{bc}$ & $3 a$ & $5.53 \mathrm{a}$ & $9.8 \mathrm{~b}$ & $1.4 \mathrm{a}$ \\
\hline 14 & $2.66 \mathrm{~d}$ & $2 b$ & $4.10 \mathrm{bc}$ & $8.2 \mathrm{c}$ & $0.2 \mathrm{~b}$ \\
\hline
\end{tabular}

Callus rating: $1=$ small, $2=$ medium, $3=$ massive callus .

* See materials and methods for the name and region of each accession.

${ }^{* *}$ Callus induction on MS+2.0 mg/L TDZ.

*** Shoot regeneration on $\mathrm{MS}+8.0 \mathrm{mg} / \mathrm{L} \mathrm{BA}+0.4 \% \mathrm{HA}$.

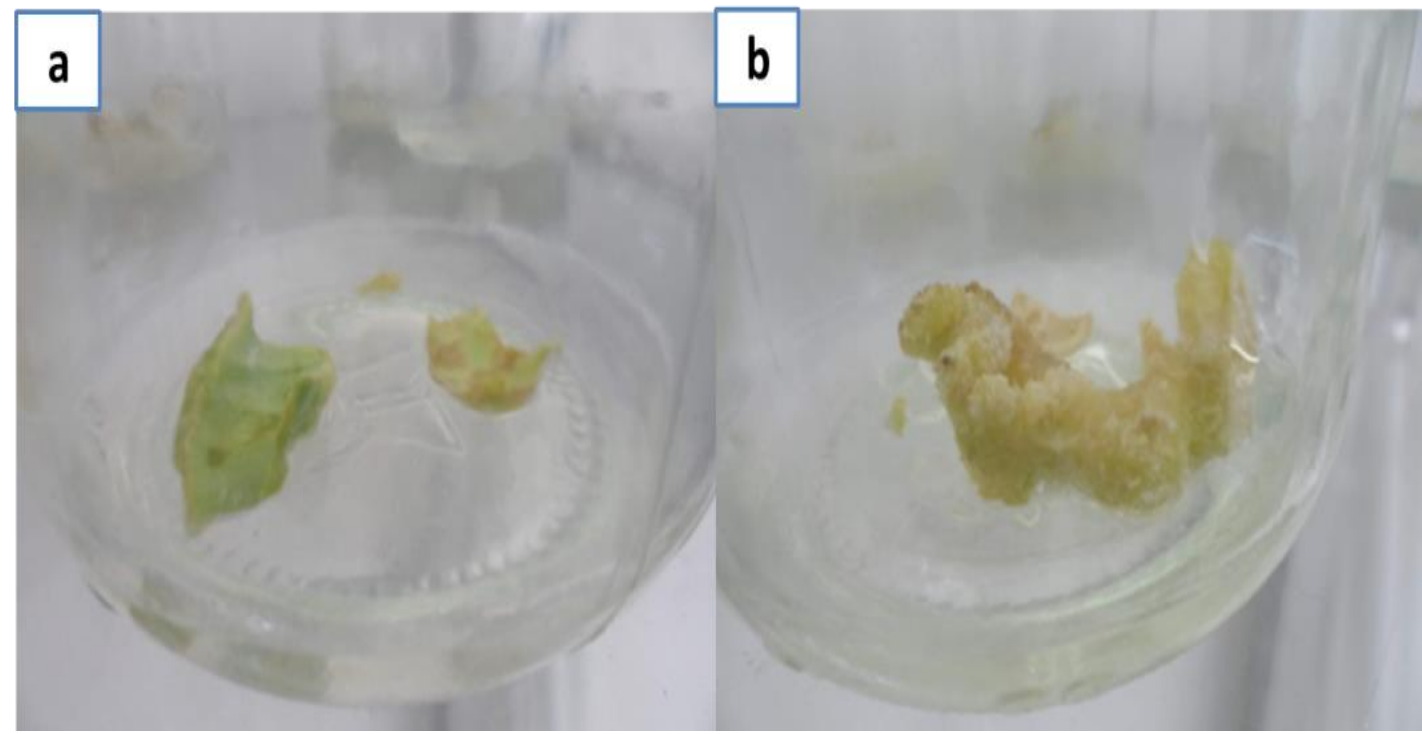

Fig. 1. No callus formation from snake melon explants on $M S+2.0 \mathrm{mg} / \mathrm{L} B A(\mathrm{a})$, and little callus from explants of accessions No.14 on the same medium 


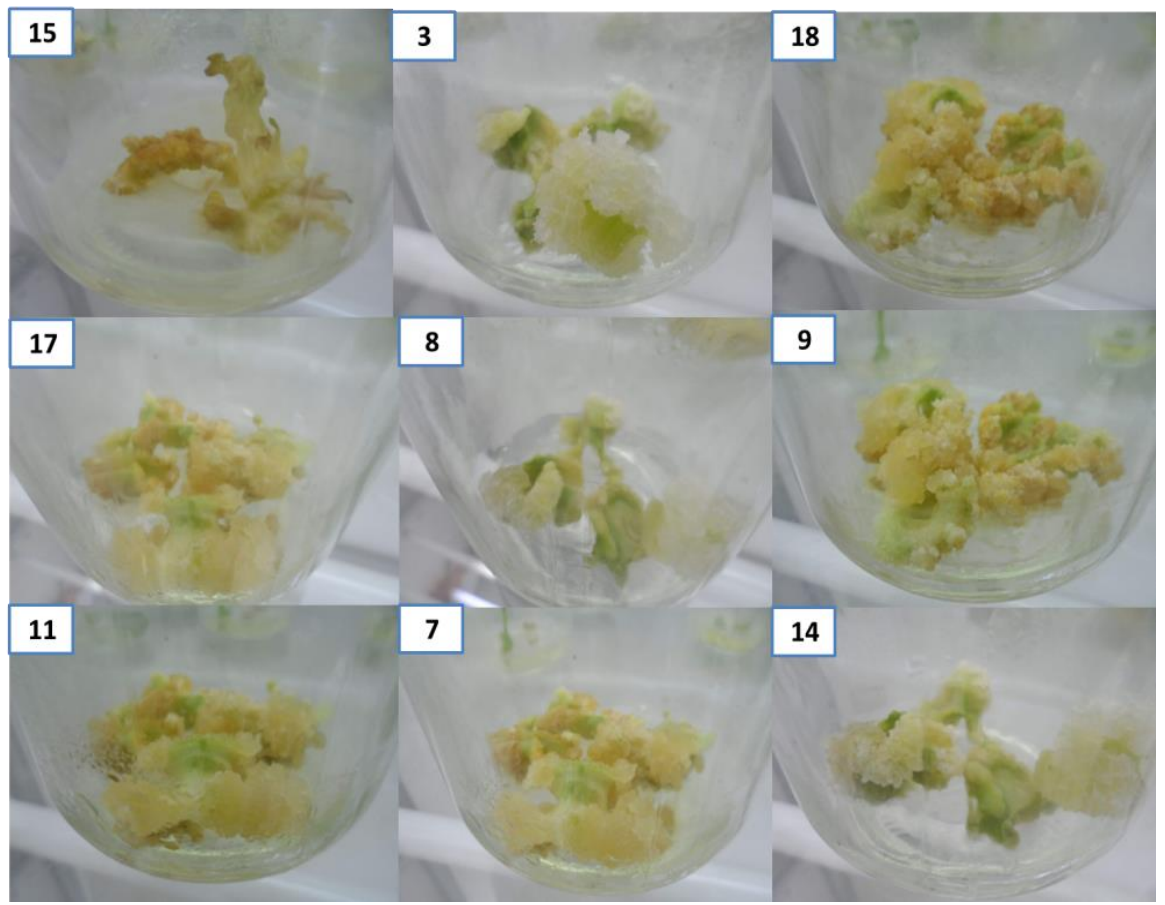

Fig. 2. Callus induction from cotyledonary explants of different Egyptian snake melon accessions. Accession No.15,3,18,17,8,9,11,7 and 14 were collected from Behaira (Wady-Natron), Damietta, Behaira (Badr), Ismailia, Fayoum, Giza, Menia, Bany Swif and Sohag, respectively.

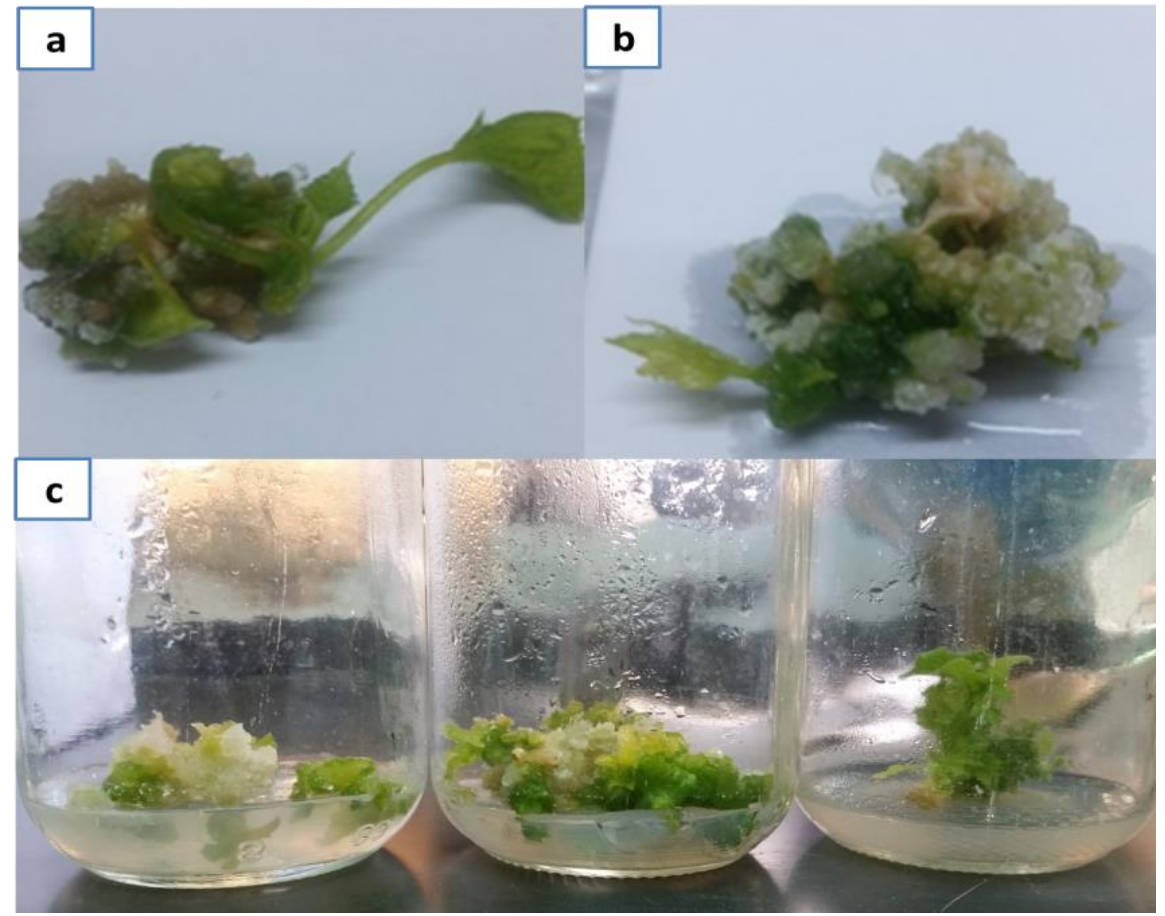

Fig. 3. Fully developed snake melon shoots from regenerated callus (a and b); developmental stages of regeneration from callus (left jar), regenerated cluster (middle) and fully developed shoots (right) jar (c). 


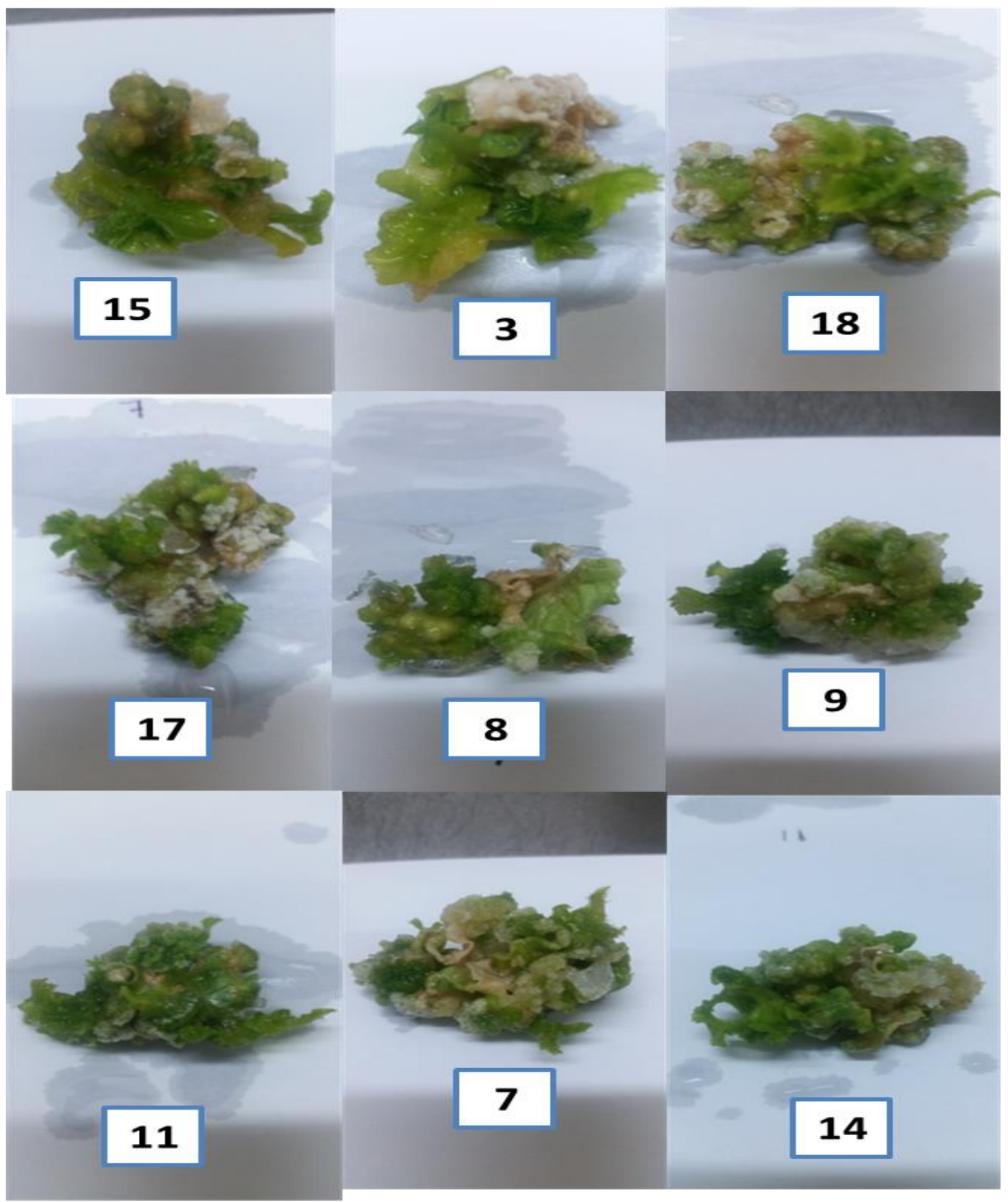

Fig. 4. In vitro shoot regeneration from callus of different snake melon accessions on $\mathrm{MS}+8.0 \mathrm{mg} / \mathrm{L}$ $\mathrm{BA}+0.4 \%$ HA. Accessions No. 15, 3,18,17,8,9, 11, 7 and 14 were collected from Behaira (Wady ElNatron), Damietta, Behaira (Badr), Ismailia, Fayoum, Giza, Menia, Bany Swif and Sohag, respectively

in vitro and almost had the same potential for callus induction. Other genotypes (No.15, and 8) had the lowest shoot regeneration capacity. It was also obvious that callus and shoot regeneration in the tested snake melon genotypes did not depend on the location from which they were collected. In this regards, accessions with the highest shoot regeneration were acc. No.7 from Bany Swif, acc. No.18 from Behaira, and acc. No.9 from Giza, all were collected from wider distances from each other. In the two in vitro experiments reported herin, all factors of in vitro culture (explants source and size, medium components and incubation conditions) were similar and the only variable was the snake melon genotype. However, significant differences exist among these genotypes in their totipotent nature to from callus and regenerate shoots in vitro. If these differences were due to their different genetic makeup, one might assume that accession with high in vitro growth potential (acc.No.9, and 18 ) or those with low potential (acc. No.15, 8, 14) might be closely related. In fact, ISSR analysis indicated that, most genotypes examined had close genetic similarity (Mohamed et al 2019). In 
accordance with the results of Molina and Nuez (1995) in melon, it was possible to detect genotypic variation when the genotypes differ by at least $10 \%$ in their regeneration ability. The existence of genetic variability affecting the regeneration among melon genotypes was also reported in several studies (Mackay et al 1988; Dirks \& Buggenum, 1989; Niedz et al 1989; Molina \& Nuez, 1995, and Ficcadenti \& Rotino, 1995).

The stimulatory effect of the cytokinin (BA) on the in vitro shoot regeneration of snake melon in our study is well documented according to the study of Yalcin-Mendi et al (2010 a,b) and Comlekcioglu et al (2009). However, they used lower concentration of BA in the medium $(0.25-2.0 \mathrm{mg} / \mathrm{L})$ than that used in the present study (8.0 $\mathrm{mg} / \mathrm{L})$. Perhaps the different response to BA concentration could be due to differences in the genetic background between the Turkish and Egyptian snake melons. In addition, due to the high level of $\mathrm{BA}$ in combination with the addition of $\mathrm{HA}$ to the culture medium (as a new plant growth regulator), high number of regenerated shoots from the different snake melon accessions was achieved. These results are in harmony with those of Kaewjampa et al 2012 in micro propagation of hybrid cymbidium, and Hefni, 2018 on shoot regeneration of $\mathrm{Cu}$ cuma longa using $\mathrm{HA}$ in the medium. The functions of hyaluronic acid (HA) include regeneration of protein secretion, gene expression, cell proliferation and differentiation (Fraser et al 1997).

In conclusion, this study demonstrated for the first time the induction of callus on TDZ-amended medium and shoot regeneration on MS medium supplemented with $8.0 \mathrm{mg} / \mathrm{L} \mathrm{BA}+0.4 \mathrm{HA}$ in different Egyptian snake melon genotypes. This protocol allowed ranking snake melon accessions collected from different regions in Egypt based on their callus and shoot regeneration potential under in vitro condition. Shoot regeneration protocol is considered the first step in any genetic engineering program and the utilization of biotechnology for the improvement in snake melon plants. Another advantage of our protocol is the possibility of introducing new trait (high regeneration capacity) into the genotype of low regeneration potential. Finally, in vitro micro propagation system can be a useful tool for germplasm preservation in vitro of snake melon grown in Egypt to be used in future breeding programs. Somaclonal variations among regenerated plant in snake melon are another tool for future studies in their breeding strategy.

\section{REFERENCES}

Ampormah-Dwamena C., Conner A.J. and Fautrier A.G. 1997. Genotypic response of lettuce cotyledons to regeneration in vitro. Scientia Hort., 71, 137-145.

Ananthakrishnan G., Xia X., Elman C., Singer S., Paris H.S., Gal-ON A. and Gaba V. 2003. Shoot production in squash (Cucurbita pepo) by in vitro organogenesis. Plant Cell Rep., 21, 739-746.

Blackmon W.J. and Reynolds B.D. 1982. In vitro shoot regeneration of Hibiscus acetosella, muskmelon, watermelon and winged bean. Plant Physiol. Biochem., 17, 558-589.

Bouabdallah L. and Branchard M. 1986. Regeneration of plants from callus cultures of $\mathrm{Cu}$ cumis melo L.Z. Planzenzuchtung, 96, 82-85.

Chevrier N., Quoreshi J.A., Hull P. and Kartha K.K. 1990. Heritability of in vitro regeneration in wheat ( $T$. aestivum L.). Canadian J. of Plant Sci., 70, 547-550.

Comlekcioglu N., Mendi Y.Y., Eldogan S. and Unek C. 2009. Effects of different combinations and concentrations of growth regulators and photoperiod on somatic embryogenesis of $\mathrm{cu}$ cumis melo var. flexuosus. African J. Biotechnology, 8(22), 6228-6232.

Compton M.E. and Gray D.J. 1993. Shoot organogenesis and plant regeneration from cotyledons of diploid, triploid, and tetraploid watermelon. J. Amer. Soc. Hort. Sci., 118, 151-157.

Curuk S., Ananthakrishnan G., Singer S., Xia X., Elman C., Nestel D., Cetiner S. and Gaba V. 2003. Regeneration invitro from the hypocotyls of Cucumis species produces almost exclusively diploid shoots, and does not require light. HortScience, 38, 105-109.

Dirks R. and van Buggenum M. 1989. In vitro plant regeneration from leaf and cotyledon explants of Cucumis melo L. Plant Cell Rpt., 7, 626- 627.

Ficcadenti N. and Rotino G.L. 1995. Genotype and medium affect shoot regeneration of melon. Plant Cell, Tissue and Organ Culture, 40, 293-295.

Fraser J.R.E., Lauren T.C. and Laurent U.B.G. 1997. Hyaluronan: its nature, distribution, functions and turnover. J. Inter. Medic., 242, 2733.

Gisbert C., Picó B. and Nuez F. 2011. Regeneration in selected Cucurbita spp. germplasm. Cucurbit Genetics Cooperative Report, 33-34, 53-54. 
In vitro callus induction and shoot regeneration potentials in some snake melon accessions collected from different regions in Egypt

Gondval M., Chaturvedi P. and Gaur A.K. 2016. Thidiazuron-induced high frequency establishment of callus cultures and plantlet regeneration in Aconitum balfourii Stapf, an endangered medicinal herb of North-West Himalayas. Indian J. Biotech., 15(2), 251-255.

Gray D.J., McColley D.W. and Compton M.E. 1993. High-frequency Somatic Embryogenesis from Quiescent Seed Cotyledons of Cucumis melo Cultivars. J. Amer. Soc. Hort. Sci., 118(3), 425-432.

Han J.S., Kim C.K., Park S.H., Hirschi K.D. and Mok I. 2005. Agrobacterium-mediated transformation of bottle gourd (Lagenaria siceraria Standl). Plant Cell Rep., 23, 692-698.

Hefni M.M. 2018. Use of Biotechnology for multiplication and development of Curcuma longa $L$. plants. Ph.D. Thesis, Dept. of Hort., Fac. of Agric., Suez Canal Univ., Ismailia, Egypt.

Higgins P. and Mathias R.J. 1987. The effect of 48 chromosomes of hexaploid wheat on the growth and regeneration of callus cultures. Theor. Appl. Genet., 74, 439-444.

Kaewjampa N., Shimasak K. and Nahar S.J. 2012. Hyaluronic acid can be a new plant growth regulator for hybrid Cymidium micropropagation. Plant Tissue Culture and Biotech., 22(1), 59-64.

Keng C.L. and Hoong L.K. 2005. In vitro plantlets regeneration from nodal segments of muskmelon (Cucumis melo L.). Biotechnol., 4, 354357.

Lazar M.D., Chen T.H.H., Scoles G.J. and Kartha K.K. 1987. Immature embryo and anther culture of chromosome addition lines of rye in Chinese spring wheat. Plant Sci., 5I, 77-81.

Lee Y.K., Chung W.I. and Ezura H. 2003. Efficient plant regeneration via organogenesis in winter squash (Cucurbita maxima Duch.). Plant Sci., 164, 413-418.

Mackay W.A., Ng T.J. and Hammerschlag F.A. 1988. Plant regeneration from callus of $\mathrm{Cu}$ cumis melo L., Cucurbit Genetics Cooperative Report, 11, 33-34.

Mohamed F.H., Beltagi M.S. and Ismail M.A. 2005. Explant source and genotype effects on the in vitro callus growth, organogenesis, and somatic embryogenesis of cucumber. Proc. $6^{\text {th }}$. Arab Hortic. Conference, Ismailia. Egypt.

Mohamed F.H., Beltagi M.S., Ismail M.A. and Omar G.F. 2007. High frequency, direct shoot regeneration from greenhouse derived leaf disk of six strawberry cultivars. Pak. J. Biol. Sci., 10(1), 96-101.
Mohamed F.H., Abo-Zeid A.E., Abd El-Hamed K.E., Elwan M.W.M. and Abdel Salam M.M. 2019. Genetic diversity in Egyptian snake melon accessions as revealed by inter simple sequence repeat (ISSR) markers. (Submitted).

Molina R.V. and Nuez E. 1995. Characterization and classification of different genotypes in a population of Cucumis melo based on their ability to regenerate shoots from leaf explants. Plant Cell, Tissue and Organ Culture, 43, 249-257.

Murashige T. and Skoog F. 1962. A revised medium for rapid growth and bio-assay with tobacco tissue cultures. Phys. Plantarum, 15, 473-497.

Murthy B.N.S., Murch S.J. and Saxena P.K. 1998. Thidiazuron: A potent regulator of in vitro plant morphogenesis. In Vitro Cellular and Developmental Biology-Plant, 34, 267-275.

Nadolska-Orezyk A. and Malepszy S. 1989. In vitro culture of Cucumis sativus L:Genes controlling plant regeneration. Theor. Appl. Genet., 78, 836-840.

Niedz R.P., Smith S.S., Dunbar K.B., Stephens C.T. and Murakishi H.H. 1989. Factors influencing shoot regeneration from cotyledonary explants of Cucumis melo. Plant Cell, Tissue and Organ Culture, 18, 313-319.

Nunez-Palenius H.G., Gomez-Lim M., OchoaAlejo N., Grumet R., Lester G. and Cantliffe D.J. 2008. Melon fruits: genetic diversity, physiology, and biotechnology features. Crit. Rev. Biotechnol., 28, 13-55.

Oridate T., Atsumi H. Ito S. and Araki H. 1992. Genetic differences in somatic embryogenesis from seeds in melon (Cucumis melo L.). Plant Cell, Tissue and Organ Culture, 29, 27-30.

Orts M.C., Garcia-Sogo B., Roche M.V., Roig L.A., and Moreno V. 1987. Morphogenetic response of calli derived from primary explants of diverse cultivars of melon. HortScience, 22(4), $666 \mathrm{p}$.

Sebastiani M.S. and Ficcadenti N. 2016. In vitro plant regeneration from cotyledonary explants of Cucumis melo L. var. Cantalupensis and genetic stability evaluation using RAPD analysis. Plant Cell, Tissue and Organ Culture, 124(1), 69-79.

Steel R.G.D. and Torrie J.H. 1980. Principles and procedures of statistics. $2^{\text {nd }}$ ed. McGraw-Hill Book, New York. 633 p.

Trivedi M., Yadav S.K., Yadav G.K., Bhaskar R., and Tiwari R.K. 2010. Thidiazuron induced 
callus induction and in vitro regeneration of Asparagus (Asparagus racemosus Wild.). Indian J. of Scientific Research, 1, 27-30.

Yalcin-Mendi Y., Comlekcloglu N., Ipek M., Kocaman E., Izgu T., Tekdal D. and Curuk P. 2010a. The effect of different hormone concentrations and dark pretreatment on adventitious shoot regeneration in snake melon (Cucumis melo var. flexuous). Romanian Biotechnol. Letters, 15(4), 5392-5395.
Yalcin-Mendi Y., Eldogan S., Gutakev R., Ipek M., Curuk P. and Cetiner S. 2010b. Regeneration and histological analysis of snake melon (Cucumis melo var. flexuosus (L.) Naudin) by direct organogenesis. Turk. J. Agric. For., 34, 309-317.

Zhang H., Peng G. and Feishi L. 2011. Efficient plant regeneration from cotyledonary node explants of Cucumis melo L. African J. Biotechnol., 10(35), 6757-6761. 
مجلة اتحاد الجامعات العربية للعلوم الزراعية، جامعة عين شمس، القاهرة، مصر مجلا(27)، عدد(4)، 2233-2223، 2019

Website: http://ajs.journals.ekb.eg

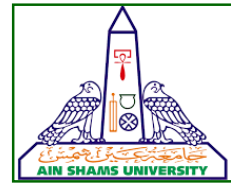

2233

كفاءة تكوين الكالوس وتجديد التبرعم الخضري معمليا في بعض سلالات القثاء المجمعة من مناطق مختلفة في مصر معري

[177]

فؤاد حسن محمد1 - أميرو احمد ابوزيد2 - خالد السيد عبد الحميد1" - محمد وصفي علوان 1 -

\section{محمد محمد عبد السلام2}

1- قسم البساتين - كلية الزراعة - جامعة قناة السويس- الإسماعيلية - مصر

2- معهد بحوث البساتين - مركز البحوث الزراعية - الدقى - الجيزة - مصر الاعلية

*Corresponding author: khalidegy1@yahoo.com

Received 13 May, $2019 \quad$ Accepted 13 October, 2019

الاعلي الي الأقل كالتالي : السلالة رقم 9 ثم رقم 18

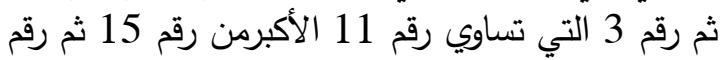

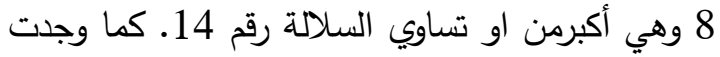
فروق معنوية بين السلالات في القدين القدرة العلي التبرعم

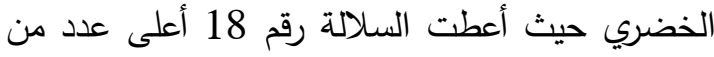

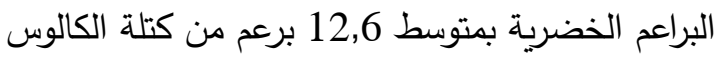

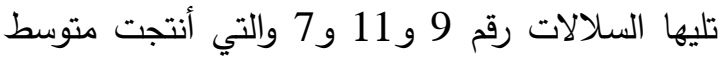

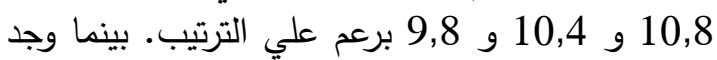
أن أقل السلالات في التبرعم الخضري كانت التر السلالة

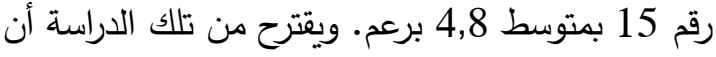

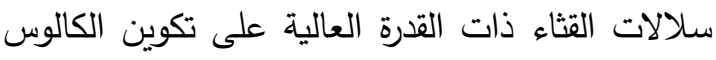

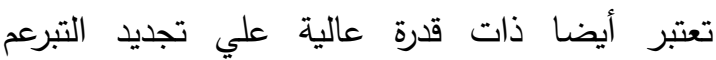
الخضري بمزارع الأنسجة إضافة الي أن هذه السئ السلالات

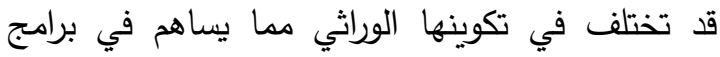
التربية في هذا المحصول.

الكلمات الدالة: القثاء، احداث الكالوس، التبرعم الخضري، حمض الهيلورونك، ثيادوزورون احلئ

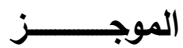

استهدفت الدراسة تقسيم بعض الأصول الوراثية

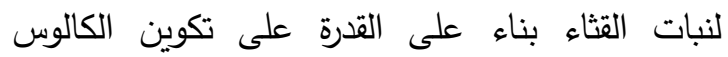

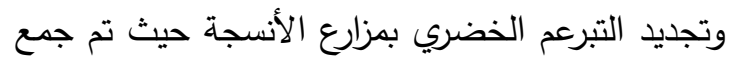

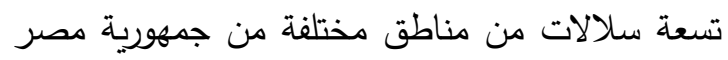

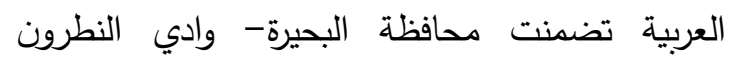
(سلالة 15) والبحيرة- مركز بدر (سلالة 18) ودمياط (سلالة 3) والجيزة (سلالة 9) واليجة والمنيا (سلالة211) وبني سويف (سلالة 7) والاسماعيلية (سلالة 17) وسوهاج

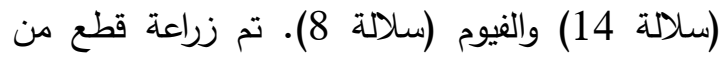
الأوراق الفلقية على بيئة موراشيج وسكوج المضاف

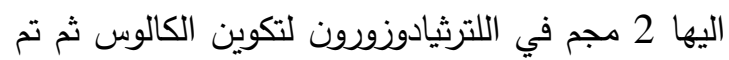
نقل الكالوس المتكون الي بيئة مضاف اليها 8 مجنم

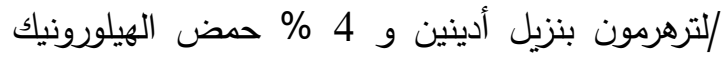

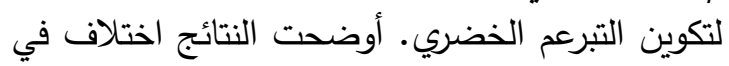
درجة تكوين الكالوس بين السلالات المختلفة وأمكن النافي ترتيب السلالات حسب الوزن الطازج للكالوس من لـن 